\title{
Filozofia wolności**
}

Philosophy of freedom. The presented text includes a review of various philosophical approaches to freedom categories, which, according to the author, is a relational term and experience. In his arguments, the researcher discusses freedom in correlation with i.a. such topics as independence, rootedness, sovereignty, the ability to act autonomously and to make independent decisions, etc. In his contemplations, the author elucidates the category of freedom both from a negative and a positive point of view, referring to the thoughts of Epictetus, G.W.F. Hegel, H. Bergson, F. Nietsche, E. Mounier, J.P. Sartre, R. Ingarden, and M. Buber.

Keywords: freedom, independence, autonomy

Wolność to niepodległość. Będąc niepodległością, jest jednocześnie jednak w rozmaity sposób podległa. Nasuwa się bowiem pytanie: w stosunku do czego jest niepodległością? I to stwierdzenie „w stosunku do czego?” ukazuje, że wolność jest pojęciem i doświadczeniem relacyjnym.

Nie jesteśmy niepodlegli w stosunku do czasu. Nikt nie wybrał sobie epoki życia, podobnie jak i samego swojego życia. Nie jesteśmy niepodlegli wobec kultury i języka. Nasze doświadczenie wolności rodzi się już w obszarze jakiejś kultury i języka. Nie jesteśmy niepodlegli w stosunku do rodziny, jej tradycji, religii, jej uwarunkowań. Podobnie jak nie jesteśmy niepodlegli wobec zdarzeń losu. Tak jak nie

* Adres do korespondencji: Wydział Humanistyczny AGH im. St. Staszica, ul. Gramatyka 8a, 30-071 Kraków. E-mail: tgadacz@agh.edu.pl.

** Publikacja tekstu za następującym źródłem: T. Gadacz, Filozofia wolności, marzec 2018, https:// www.goethe.de/ins/pl/pl/kul/sup/fee/21184099.html (dostęp: 11.01.2020). Redakcja dziękuje Autorowi oraz Goethe-Institut w Polsce za wyrażenie zgody na umieszczenie tekstu w niniejszym tomie. 
mamy wpływu na czas naszego życia, rodzinę, tak też nie panujemy nad zdarzeniami losu. Wolność nie jest absolutna. Jest zawsze w jakiejś sytuacji. Będąc wolni, możemy jednak kształtować naszą sytuację. I tym wolny człowiek różni się od przedmiotu. Drzewo zrzucone do rzeki musi płynąć z jej prądem. Człowiek, jeśli zechce, może płynąć pod prąd. Świadom tego był Plotyn, pisząc, że nie mamy wpływu na rolę, jaką przyszło nam grać w dramacie egzystencji, rolę przydzieloną przez los. Mamy jednak wpływ na samą grę.

Ta niepodległość $\mathrm{w}$ różnych postaciach podległości stanowi dla nas jednocześnie zobowiązanie. Jesteśmy zobowiązani wobec własnej epoki, ojczyzny, kultury, języka, rodziny, jej tradycji, religii, wreszcie wobec naszego własnego życia. Czasami dla niektórych osób to zobowiązanie może być doświadczane jako ograniczenie albo nawet ciążące kajdany. Dlatego niektórzy zmieniają kraj, język, usiłują zerwać $\mathrm{z}$ własną tradycją. Dokonując takiego zerwania, muszą jednak zakorzenić się gdzieś indziej albo wybrać los wiecznych wędrowców.

Wolność jest zawsze zakorzeniona. Rozważmy, co oznacza stwierdzenie: „Ja jestem wolny"? Co oznacza ,ja”? Ja jestem zakorzeniony w ziemi, na której się urodziłem, w kulturze i religii, w jakiej zostałem wychowany, w wartościach, które zostały mi przekazane, w mowie, którą mówię, w rodzinie. To wszystko jest moje: ziemia, język, religia, kultura, wartości, rodzina. Te wszystkie związki określają mnie, moje „ja”. Dopiero mając określoną tożsamość, mogę rozumieć moją wolność. Wolność nie jest więc abstraktem, wyzwoloną i wykorzenioną siłą. To zakorzenienie nie stanowi dla wolności ograniczenia. Wręcz przeciwnie, jest warunkiem jej istnienia. Bez tego zakorzenienia wolność może przemienić się w niszczącą siłę. Nie oznacza to oczywiście, że nie mogę zmienić ojczyzny, języka czy przyjaciół. Mogę je zmienić właśnie dlatego, że jestem wolny. Ale przecież będzie to znowu określone zakorzenienie. I wierność temu zakorzenieniu jest warunkiem bycia wolnym. Wolność nie może więc podcinać swoich korzeni.

Wolność jest niezależnością. Absolutna niezależność byłaby jednak absolutną samotnością. Wolność jest międzyludzka.

Gdyby człowiek był sam na świecie, nie byłby prawdopodobnie świadom wolności. Być może doświadczałby swobody jako otwartości przestrzeni. Nie uznałby jednak za ograniczenie swej wolności czegoś, co nie byłoby zgodne z jego naturą, na przykład tego, że nie może przespacerować się na Księżyc. Uznałby natomiast za ograniczenie wolności fakt, że ktoś zakazałby mu publicznej działalności. W związku z tym stajemy przed pytaniem: czy wolność innego jest granicą mojej wolności, czy szansą ofiarowaną mojej wolności? Tego dylematu świadom był szczególnie Jean-Paul Sartre.

Swoje najbardziej znane poglądy na temat wolności przedstawił w Bycie i nicości. Wolność pojmował tam po heglowsku, jako „bycie u siebie”. Dopóki pozostajemy sami w relacji do przedmiotów, układamy je i porządkujemy we własnym świecie. Jeśli natomiast pojawi się w tym świecie inny, rodzi się konflikt. Wyraża się on w uprzedmiotowieniu przez spojrzenie. Usiłujemy wpasować innego we własny 
świat. Inny jednak nie jest przedmiotem, jest równie wolny, dlatego usiłuje podobnie uczynić z nami. To właśnie doświadczenie wyraził Sartre w znanym zdaniu: „Piekło to inni” ${ }^{\prime}$. Nie chodzi jednak o to, by zapanować nad innym jak nad zwykłą rzeczą. Chcemy panować nad innym jako wolnym, a zatem chcemy posiadać go jednocześnie jako przedmiot i jako wolność. W analizach normalnego i patologicznego życia płciowego Sartre usiłował pokazać, że chodzi wciąż o zapanowanie nad cudzą wolnością. Nie tylko pożądanie czyjegoś ciała, lecz także innego. Nie jest to jednak możliwe. Wciąż jesteśmy winni, uprzedmiotawiając innego lub dając się mu uprzedmiotowić. Odkrycie wolności innego, a przez to także własnej wolności, dokonuje się pierwotnie $\mathrm{w}$ walce.

Jeśli w Bycie i nicości inny „był piekłem”, to w Cahiers pour une morale, dziele napisanym kilka lat po poprzednim, opublikowanym jednak dopiero po śmierci Sartre’a (w 1983 roku), można mówić o zmianie nastawienia do innego. Stwierdził w nim Sartre, że nie można mieć na celu swej wolności, nie mając jednocześnie na celu wolności innego. Rozważył trzy rodzaje spotkania innego: prośbę, wymaganie i apel. Prośba i wymaganie to dwa warianty relacji między panem i niewolnikiem. W prośbie niewolnik sam podporządkowuje się panu, prosząc jedynie o łaskę. Wyrazem takiego podporządkowania jest modlitwa do Boga jako Pana. Natomiast w wymaganiu Pan żąda podporządkowania się niewolnika, czyniąc w ten sposób z jego wolności przedmiot. Apel, odmiennie niż prośba i podporządkowanie, odsłania dwie ludzkie wolności znajdujące się zawsze w jakiejś sytuacji, z których jedna uznaje drugą i zwraca się do niej. Nie są one względem siebie w relacji nadrzędnej (nakaz) czy podrzędnej (prośba), lecz równorzędnej. Jest to wezwanie do solidarnego działania, w którym poszanowana jest wolność każdej ze stron. Apel jest jednocześnie wezwaniem skierowanym do wolności innego i darem, a realizowana w nim moralność jest wspaniałomyślna i darmowa. Moralność apelu przedstawił Sartre w obrazie człowieka znajdującego się na platformie autobusu, który ruszył z przystanku. Widząc, jak inny do niego podbiega, wyciąga rękę, by mu pomóc wskoczyć do środka. Gdy biegnący sam wyciąga rękę, staje się darem dla tego, który rękę do niego wyciągnął. Rodzi się nowa wartość, jak w akcie twórczym: „Istnieje wzajemne pobudzenie każdej wolności i każda jest naraz u źródeł innej”"

Inny nie jest zatem granicą mojej wolności. Wręcz przeciwnie - jego wolność jest szansą dla mojej wolności, szansą wzajemnego obdarowania. Może jednak być także granicą. Ten nowy pogląd Sartre’a nie znosi możliwości wyrażonej poprzednio. Jeśli jednak wolność jest międzyludzka, nie można w projekcie własnej wolności nie uwzględniać wolności innych. Inaczej błędnie rozumiemy wolność jako samowolę, jako wolność imperatora. Polega ona nie tylko na tym, że czyni to, co chce, lecz także na tym, że często czyni to wbrew innym. Człowiek samowolny usiłuje być wolny

1 J.P. Sartre, Dramaty. Muchy; Przy drzwiach zamkniętych; Ladacznica z zasadami; Niekrasow, przeł. J. Lisowski, J. Kott, Warszawa 1956, s. 176.

2 J.P. Sartre, Cahiers pour une morale (1947-48), Paris 1983, s. 300. 
w taki sposób, jak gdyby był sam na świecie. Platon określił tę wolność mianem wolności despoty, Georg Wilhelem Friedrich Hegel — mianem wolności imperatora.

Jeśli wolność jest relacyjna, to możliwa jest jedynie w relacji do innych osób. Wolność nie jest zatem celem w sobie samym. Niejednokrotnie wolność przeciwstawia się przymusowi. Rację ma jednak Martin Buber, twierdząc, że przeciwieństwem przymusu nie jest, jakby się mogło zdawać, wolność, lecz wspólnota, więź. Wolność jest środkiem, przejściem, szansą ofiarowaną dla tworzenia więzi. Jest jak most, po którym się przechodzi, ale na którym się nie mieszka ${ }^{3}$. Inni ludzie nie są więc, jak sądzą doktryny liberalne, granicą mojej wolności. Inni od samego początku moją wolność zobowiązują i ją spełniają.

Wolność jest nie tylko niepodległością, ale także możliwością autonomicznego działania. Każdy mój czyn jest wolny, o ile jest moim czynem. Tymczasem wolny czyn musi być nie tylko autonomiczny, lecz także autentyczny. Sprawcą moich czynów jestem ja sam.

Ten aspekt wolności Roman Ingarden nazwał fenomenem wolności. Czyn wolny jest czynem własnym. A czyn własny pojawia się tam, gdzie istnieje samodzielność, zarówno w myśleniu, jak i w działaniu. Samodzielność nie oznacza oczywiście samowystarczalności, wykluczenia współpracy z innymi czy otwartości na świat. Samodzielnym, czyli wolnym, jest człowiek wówczas, gdy potrafi zająć własne stanowisko ${ }^{4}$. Własne stanowisko oznacza tu niezależność, swobodę w stosunku do uzyskanej wiedzy, nauki i kultury. Taka samodzielność musi wypływać jednak z centrum człowieka. „To nie z jego peryferii, nie z jego codziennych sposobów zachowania musi płynąć samodzielność, tylko musi być zakorzeniona w ostatecznym rdzeniu człowieka" "5. Gdy nie ma samodzielności, pisze Ingarden, to w pewnym znaczeniu nie ma człowieka. Ten pogląd, że czyny samodzielne, własne, a zatem wolne wypływają z rdzenia człowieka, mógł Ingarden zaczerpnąć od Henriego Bergsona, dla którego wolność jest przyczyną własnych aktów, spontanicznością własnych inicjatyw. Czujemy, że jesteśmy przyczyną tego, co czynimy, czyli czujemy, że jesteśmy wolni. Wolność, choć nie może być dowiedziona, może być przeżywana i doświadczana, dana intuicyjnie. Kluczem do Bergsonowskiej koncepcji wolności jest rozróżnienie „ja powierzchniowego" $i$,ja głębokiego". „Ja powierzchniowe” ma charakter zewnętrzny, jest „ja” bezosobowym i społecznym. „Ja głębokie” jest osobowe, niepowtarzalne.

W miarę jak schodzimy z tej powierzchni w głąb naszego ja, pisał, w miarę jak nasze ja staje się znowu sobą, w takim stopniu również stany świadomości przestają się szeregować, a zaczynają się przenikać, zlewać się razem i zabarwiać, każdy swoim kolorytem wszystkie inne. Podobnie jak każdy z nas ma swój sposób miłowania i nienawiści, a w tej miłości i nienawiści odbija się cała nasza osobowość

Czyn wolny jest czynem „ja głębokiego”. Akty ludzkie są jednak najczęściej aktami „ja powierzchniowego", dlatego nie są wolne. Wydaje nam się, że jesteśmy wolni, gdyż

\footnotetext{
3 M. Buber, „Wychowanie”, Znak 1968, nr 166, s. 449.

${ }^{4}$ Por. R. Ingarden, Wykłady z etyki, oprac. A. Węgrzecki, Warszawa 1989, s. 234.

5 Ibidem.

${ }^{6}$ H. Bergson, Oeuvres. Edition du centenaire, red. A. Robinet, Paris 1963, s. 113 [przeł. T.G.].
}

Miscellanea Posttotalitariana Wratislaviensia 8, 2020

(C) for this edition by CNS 
jesteśmy autonomiczni. Polega to jednak na tym, że żyjemy tak, jak „się żyje”, czytamy książki, które aktualnie „się czyta”, oglądamy filmy, które „się ogląda”, bywamy w miejscach, w których wypada bywać. Doświadczenie wolności jest zatem rzadkie.

Ten autentyczny wymiar wolności utożsamiamy z samą osobą. Osoba, wolność, autentyczność są więc pod pewnym względem synonimami. Wolność powinna być zatem nie tylko autonomiczna, ale i autentyczna. Jeśli autonomiczność wyraża się we wszystkich czynach, to autentyczność szczególnie w dziełach twórczych i w międzyosobowych relacjach, jak miłość, wierność, szacunek itp. Wolnym nie może być zatem ktoś, kto nie jest sobą.

Człowiek ma zarówno tożsamość substancjalną, jak i wewnętrzną. Pierwsza stwierdza fakt bycia tym samym. Każdy jest tym samym od narodzin po śmierć. Dlatego może być podmiotem autonomicznego działania oraz ponosić, nawet po wielu latach, odpowiedzialność za własne czyny. Nośnikiem tej tożsamości jest fizyczność (kod genetyczny, linie papilarne). Druga tożsamość to tożsamość wewnętrzna: „bycie sobą samym". Podstawą tej drugiej tożsamości jest wierność sobie i wyznawanym przez siebie wartościom. Kto jest wiernym sobie, jest człowiekiem przewidywalnym. Przeciwieństwem takiej tożsamości jest człowiek bez właściwości. To ktoś, kto przypomina tykwę, w środku pustą, którą można wypełnić każdą dowolną treścią w zależności od koniunktury. Raz można być demokratą, innym razem autokratą, raz uniwersalistą, raz nacjonalistą. Przyczynia się do tego panowanie osobowości merkantylnej, dla której bardziej liczy się to, jak się sprzedać na rynku, niż to, kim jesteśmy. Skoro za każdym razem jest się kimś innym, to nie wiadomo, kto jest tu wolny.

\section{Wolność wewenętrzna}

Jeśli wolność jest niepodległością, to nie może to być tylko niepodległość zewnętrzna. Z niepodległością zewnętrzną mamy do czynienia wówczas, gdy ktoś nie jest niczyim niewolnikiem, czy więźniem. Ma także otwarte możliwości wyboru i samorealizacji. Jego wolność nie jest zewnętrznie ograniczona. Przejawem takiej wolności jest możliwość poruszania się bez granic, wyznawania określonej religii, głoszenia poglądów politycznych, wolnego wyboru kształcenia, pracy. Istota wolności polega jednak na niepodległości wewnętrznej.

Jeżeli człowiek jest wewnętrznie wolny, może być także wolny w każdej sytuacji, nawet w najbardziej ekstremalnych warunkach.

Natomiast jeżeli nie jest wewnętrznie wolny, to nawet stworzenie odpowiednich prawnych i konstytucyjnych warunków wolności nie zagwarantuje mu wolności. „Nie można dać człowiekowi wolności z zewnątrz, pisał Emmanuel Mounier, wraz z życiowymi ułatwieniami czy konstytucjami: zasną w swych wolnościach i obudzą się jako niewolnicy. Wolności są jedynie szansami ofiarowanymi duchowi wolności”’

\footnotetext{
7 E. Mounier, Oeuvres Completes, t. 3, Paris 1961-1962, s. 483 [przeł. T.G.].
} 
Wolność wewnętrzną jako niepodległość opisali dość szczegółowo stoicy, szczególnie Epiktet w Diatrybach. Przyjmowali oni rozróżnienie między tym, co niewolitywne, a tym, co wolitywne. To, co niewolitywne, to rzeczy zewnętrzne, które nie zależą od nas i które możemy łatwo utracić. Kto przywiązuje się do nich, kto się od nich uzależnia, wraz z zależnością traci wolność. Warunkiem wolności wewnętrznej jest więc wewnętrzna niepodległość rozumiana jako brak uzależnienia. Dla Epikteta ta właśnie wewnętrzna wolność jest istotą wolności. Wolność wewnętrzna jest taką wartością, której w żaden sposób nie można nikomu odebrać. Jej gwarantem jest bowiem śmierć. Śmierć nie jest, jak niejednokrotnie się sądzi, kresem wolności, ciosem w wolność, ale właśnie jej niezbędnym warunkiem. Człowiek zagrożony utratą wolności, przymuszany do zła, do wyrzeczenia się swoich zasad czy idei, może zawsze wybrać śmierć. Wolności nie można nikomu odebrać, można ją tylko utracić. Utrata wolności jest jednak tylko ujawnieniem wcześniejszego zniewolenia. Zniewalający jest tym, który przyjmując oddawaną mu wolność, pozwala uświadomić zniewalanemu jego własne zniewolenia. A można być zniewolonym przez ambicje, karierę, materialne dobra, a nawet życie.

Znane były przypadki z minionej epoki, gdy młodego, ambitnego inżyniera wezwano na rozmowę do dyrekcji zakładu, w którym pracował. Rozmowa mogła potoczyć się tak mniej więcej: „Panie inżynierze. My pana obserwujemy. Widzimy, że jest pan człowiekiem zdolnym i ambitnym. My panu pomożemy w karierze. Ale wie pan... Musimy wiedzieć, co myślą pracownicy, o czym mówią. Pan nam będzie zdawał raporty". Ów inżynier mógł wyjść, stwierdzając, że jest to poniżej jego godności. Mógł jednak zgodzić się na współpracę. Nikt go jednak nie zniewalał. Uświadomiono mu jedynie jego wewnętrzną zależność od kariery.

\section{Zakres wolności}

Wolność jest nie tylko niepodległością, ale także możliwością podejmowania decyzji i działania. Być wolnym to móc. Jestem tym bardziej wolny, im szerszy jest zakres możliwości mojego wyboru. Jeśli mogę wybrać studia na kilkunastu uczelniach, a nie tylko na dwóch, gdy mogę zrobić zakupy w kilkunastu sklepach zamiast w kilku, gdy mogę wybrać działalność w kilku partiach politycznych zamiast tylko w jednej, to zakres mojej wolności wydaje się o wiele większy. Tak jest jednak tylko pozornie, gdyż móc, to znaczy chcieć, mieć wolę działania. Sławomir Mrożek przedstawił w In$d y k u$ następującą scenę. Oglądałem ją kiedyś w reżyserii Jerzego Jarockiego w Starym Teatrze w Krakowie. Trzech chłopów ubranych w stroje krakowskie śpi przy okrągłym stoliku. Po chwili budzi się pierwszy i mówi: „Zasialiby my co”, i usypia. Po chwili budzi się drugi i pyta: „A co?”, i usypia. Wreszcie budzi się trzeci i stwierdza: „A po co”, i usypia. A wokół świat się zmienia. Otwierają się granice, pojawiają się nowe możliwości wolności gospodarczej, społecznej, politycznej. 
By być wolnym, trzeba chcieć być wolnym. Nie wystarczy mieć wolność jako możliwość działania. Można stworzyć warunki do wolności, ale nie można nikogo przymusić do inicjatywy, do wolnego działania.

Można jednak chcieć, ale także nie móc, stając przed nieprzekraczalnymi barierami ekonomicznymi. Kiedyś, w minionym systemie politycznym, przez kilkanaście lat starałem się o paszport, by wyjechać na letnią szkołę języka niemieckiego na Uniwersytet Wiedeński, i nie mogłem. W Urzędzie Paszportowym w Krakowie umawiano mnie zawsze na piętrze, w odrębnym pokoju o określonej godzinie. Nie trzeba było być człowiekiem wykształconym, by wiedzieć, po co tam się idzie. Nigdy nie przychodziłem na czas. W okienku, na dole, gdzie stali wszyscy obywatele, dowiadywałem się, że termin minął, a ja nie otrzymałem paszportu. Tak trwało to wiele lat. Otrzymałem paszport dopiero wraz z polityczną odwilżą w Polsce. Pamiętam do dzisiaj związane z przekroczeniem granicy doświadczenie wolności, gdy przejechałem przez pas graniczny między Czechosłowacją a Austrią, po ostrej kontroli osobistej, i wysiadłem na Dworcu Zachodnim. Poczułem wolność w powietrzu, którym oddychałem. Pomyślałem, że teraz już wszystko mogę. Niestety tylko do następnego dnia, gdy stanąłem przed wystawą Księgarni Herdera w Wiedniu. Zobaczyłem wspaniałe dzieła klasyki filozofii w języku niemieckim. Chciałem kupić je wszystkie, ale nie mogłem kupić żadnego. W kieszeni miałem jedynie 10 dolarów, które każdy obywatel mógł zakupić w Polsce i legalnie wywieźć za granicę.

\section{Wolność pozytywna}

Wolności doświadczamy szczególnie w akcie wyzwolenia. Po co jednak jest wolność? Czy wolność jest tylko od czegoś, czy też ku czemuś? Czy jest tylko negatywna, czy także pozytywna?

Nie istnieje wolność negatywna bez wolności pozytywnej. Przy czym określenia „negatywny” i „pozytywny” mogą mieć różne znaczenia. Najpierw wolność negatywna to wolność od przeszkód, granic, uwarunkowań. Każdy wolny czyn, wolny wybór zawiera w sobie tak rozumiany moment negatywny. Absolutyzacja momentu negatywnego może jednak doprowadzić do utożsamienia wolności z buntem, anarchią, wolnością, której jedynym programem jest negacja. Taką wolność Hegel nazwał wolnością rewolucyjną, gdyż najczęściej przejawia się ona w rewolucyjnym fanatyzmie.

Zaliczyć do tego należy na przykład okres terroru rewolucji francuskiej, w której zniesione miały być wszelkie różnice wynikające $\mathrm{z}$ talentu i autorytetu. Był to okres wstrząsu, wzburzenia, nietolerancji wobec wszystkiego, co stanowiło jakąkolwiek szczegółowość. Fanatyzm bowiem pragnie abstrakcyjności, a nie rozczłonkowania; jeśli wyłaniają się jakieś różnice, fanatyzm uważa je za sprzeczne ze swoją nieokreślonością i znosi je. Dlatego też lud w czasie rewolucji burzył ciągle na nowo te instytucje, które był sam wprowadził... ${ }^{8}$

${ }^{8}$ G.W.F. Hegel, Zasady filozofii prawa, przeł. A. Landman, Warszawa 1969, s. 346. 
Negatywna wolność w czystej postaci nie jest jednak do końca możliwa, gdyż absolutna negacja unicestwia ostatecznie samą wolność. Wolność negatywna musi być zatem związana z wolnością pozytywną.

Wolność pozytywna jest wolnością wyboru czegoś: działania lub niedziałania, czynienia takiej lub innej rzeczy. Wolność pozytywna jest wolnością związania się z... samozwiązania. Uwalniamy się zatem od czegoś, aby się z czymś na nowo związać.

Ten związek negatywnego i pozytywnego momentu wolności przedstawił Friedrich Nietzsche w Tako rzecze Zaratustra w opisie trzech faz duchowego rozwoju, jak to wielbłąd lwem się staje, a lew dziecięciem. Wielbłąd to duch juczny, na którego grzbiet nakładane są ciężary moralnych zasad, obyczajów, wartości, religii. Gdy zbyt zaczną mu one ciążyć i zrzuci ten ciężar z siebie, zrzuca także skórę wielbłąda i staje się lwem. Wolność lwa jest wolnością negatywną. Lew wie, od czego się wyzwala, i wie, czego nie chce, ale nie wie jeszcze, czego chce. Gdy nowe zacznie tworzyć wartości, stanie się dopiero dzieckiem.

Gdy obserwowałem Wiosnę Arabską, kiedy cały świat fascynował się ruchami wyzwoleńczymi inspirowanymi przede wszystkim przez młodych ludzi, patrzyłem na te wydarzenia z obawą. To był moment wolności negatywnej. Wolności od tyranii. Stawiałem sobie jednak pytanie: co będzie dalej? Jak nastąpi przejście od wolności negatywnej do pozytywnej? Jak te społeczeństwa tę wolność zagospodarują? I dzisiaj widzimy, że jest to istotny problem, że wyzwolić się, to jeszcze nie wszystko.

Określenie „wolność negatywna” możemy jednak rozumieć także w sensie doświadczania na sposób negatywny. Według takiego rozumienia wolności największe jej doświadczenie miałby ten, kto doświadczyłby najgłębszej jej utraty. Tak jak nie można poznać światła bez ciemności, dobra bez zła, zdrowia bez choroby, tak wolności bez niewoli. Pisał Sartre:

Nigdy nie byliśmy bardziej wolni niż pod niemiecką okupacją. Utraciliśmy wszystkie nasze prawa, przede wszystkim prawo wypowiadania się. Każdego dnia rzucano nam w twarz obelgi [...] masowo nas deportowano jako Żydów, więźniów politycznych [...] Okrucieństwo wroga doprowadziło nas do granic naszej kondycji, zmuszając nas do postawienia pytań, których unika się w czasie pokoju: [...] jeśli będą mnie torturować czy wytrzymam? W ten sposób było postawione pytanie o wolność i byliśmy u szczytu najgłębszego poznania, jakie człowiek może mieć o samym sobie? ${ }^{9}$.

Sartre nie dokonał oczywiście apoteozy faszyzmu. Chciał pokazać, jak intensyfikuje się doświadczenie wolności w sytuacji doświadczeń negatywnych, śmiertelnych zagrożeń. Tak rodzi się wolność romantyczna.

W kontekście tak rozumianej negatywności wolność pozytywna przejawia się w twórczym działaniu. Ekspresja twórcza różni się od innych form ludzkiego działania. Czyny twórcze nie są nastawione na posiadanie. Nie wprowadzają też zaburzenia w dziedzinach należących do innych. Czyn twórczy jest czystym gestem, który nie porywa świata dla siebie, ale wyraża siebie dla świata ${ }^{10}$. Dokłada do niego nową wartość. Poprzez czyn twórczy osoba wyraża siebie samą i w ten sposób spełnia swą wolność.

9 J.P. Sartre, Silence III, s. 11-12, cyt. za W. Gromczyński, Człowiek, świat rzeczy, Bóg w filozofii Sartre'a, Warszawa 1969, s. 247-249.

10 Por. M. Buber, op. cit., s. 452.

Miscellanea Posttotalitariana Wratislaviensia 8, 2020

(C) for this edition by CNS 
Podkreślenie twórczego charakteru wolności jest o tyle istotne, że Polska przez dziesiątki lat doświadczała wolności romantycznej. Wolność była przedmiotem tęsknoty i walki. Nie sądzę jednak, by utrata wolności była odpowiednią drogą do jej poznania. Jeśli nawet tak, to cena, jaką się płaci za to poznanie, jest nazbyt wielka. Człowiek, który doświadcza wolności poprzez negację, w walce przeciw..., w oporze wobec..., często przestaje być zdolny do pozytywnej ekspresji wolności. Nie chcę oczywiście przekreślać znaczenia tej negatywnej drogi poznania. Była ona kuszącą propozycją w czasach, kiedy można było uzyskać łatwe i tanie samouspokojenie, że głębsze poznanie wolności ma ofiara niż jej opresor. Nie jest łatwo jednak zmienić narodową mentalność. Dlatego wolność, która nagle okazuje się możliwością pozytywistycznego działania, może okazać się nieszczęsnym darem, jak stwierdził ks. Józef Tischner.

Wolność pozytywna wymaga także pracy i trudu. Wyobraźmy sobie następującą sytuację: ktoś dokonuje wyboru swego przyszłego zawodu. Spośród wielu możliwych alternatyw, nieprzymuszony żadnymi okolicznościami zewnętrznymi ani wewnętrznymi, dokonał wyboru. Postanowił zostać skrzypkiem wirtuozem. Dokonawszy tego wyboru, musi być wolny od innych możliwości życiowej samorealizacji. Nie można zrealizować naraz wszystkich zawodów. Wybrawszy jednak, trzeba rozpocząć drugą fazę wolności, fazę pozytywną: „wolność do...”. Oto przed tym, kto wybrał zawód skrzypka wirtuoza, otwiera się świat muzyki, w którym trzeba swobodnie się poruszać. Aby było to możliwe, należy poznać zasady i prawa muzyki rządzące tą przestrzenią, a przez długie, żmudne godziny ćwiczeń osiągnąć biegłość i swobodę gry na instrumencie. Im doskonalej ów człowiek pozna zasady muzyki i im swobodniej będzie posługiwał się instrumentem, tym będzie bardziej wolny jako skrzypek, a jednocześnie tym bardziej będzie jako skrzypek doskonały. Taka wolność wymaga jednak pracy i odpowiedzialności. Praca i odpowiedzialność stanowią o sensie początkowego wyboru i sensie wolności w tym wyborze obecnej. Jaki bowiem sens miałyby wolny wybór i decyzja zostania skrzypkiem, gdyby następnego dnia ów człowiek zamknął nuty w biurku i odstawił instrument do kąta. W ten sposób uczyniłaby bezsensownym swój własny wybór i swoją własną wolność. Ów twórczy wysiłek stanowi zatem wierne potwierdzenie początkowego wyboru i coraz pełniejsze nadawanie mu sensu. Tak więc pełna i prawdziwa wolność ma swoje dwa komplementarne synonimy: wierność i doskonałość.

\section{Wolność a wiara}

Postawmy wreszcie pytanie o Boga. Czy istnienie Boga ogranicza wolność ludzką? Tak sądził Friedrich Nietzsche: „jeżeliby bogowie byli, jakżebym ja zniósł, abym bogiem nie był. Przeto nie ma bogów"11. Równie, a może bardziej istotne niż „śmierć Boga” były dla Nietzschego wypływające z niej skutki. Dopiero upadek wiary w Boga otwiera przed ludźmi możliwość pełnego rozwoju, gdyż Bóg jest zagroże-

11 F. Nietzsche, Tako rzecze Zaratustra. Książka dla wszystkich i dla nikogo, przeł. W. Berent, Warszawa 1908, s. 114.

Miscellanea Posttotalitariana Wratislaviensia 8, 2020

(C) for this edition by CNS 
niem dla woli mocy i życia. „Pomarli bogowie wszyscy: niechże więc za wolą naszą nadczłowiek żyje"12. Jeśli Bóg umarł, to człowiek nie musi już kierować się w stronę tamtego świata. „Od czasu, gdy on w grobie legł, wyście dopiero zmartwychwstali” ${ }^{3}$. Teraz człowiek rozstrzyga o prawdzie i fałszu, dobru i złu.

Rzeczywiście, my filozofowie i „duchy wolne” czujemy się na wieść, że „Bóg umarł”, jakby opromienieni nową jutrzenką; serce nasze przelewa się wdzięcznością, zdumieniem, przeczuciem, oczekiwaniem — w końcu ukazuje się nam widnokrąg znów wolny, chociaż by nawet nie był jasny, wreszcie znów mogą wybiegać okręty nasze... ${ }^{14}$

Widnokrąg wskazuje pewien kierunek. Gdzie indziej pytał jednak Nietzsche: „Kto dał nam gąbkę, by zetrzeć cały widnokrąg?" ${ }^{15}$. Nie ma już żadnych ostatecznych kierunków, „na dole” i „w górze”. Błądzimy w nieskończonej nicości ${ }^{16}$.

Odmienna jest jednak idea Sartre’a i trudno nie przyznać mu racji. „Człowiek jest tylko tym, czym siebie uczyni. Taka jest pierwsza zasada egzystencjalizmu"17. Człowiek jest twórcą samego siebie i najpierw jest, zanim jeszcze zacznie określać swą istotę. Brak Boga nie był jednak dla Sartre’a powodem do radości. Odwołując się do znanego stwierdzenia Fiodora Dostojewskiego: „Gdyby Bóg nie istniał, wszystko byłoby dozwolone", pisał:

To właśnie jest punktem wyjścia dla egzystencjalistów. W rzeczy samej, wszystko jest dozwolone, jeżeli Bóg nie istnieje, i w konsekwencji człowiek jest osamotniony, gdyż nie znajduje ani w sobie, ani poza sobą punktu oparcia. Przede wszystkim zaś nie znajduje usprawiedliwienia ${ }^{18}$.

Celem Sartre’owskiego egzystencjalizmu nie jest jednak negacja Boga, lecz uświadomienie sobie przez człowieka swej wolności.

Nie chodzi o to, czy wierzymy w istnienie Boga, bo uważamy, że to nie jest głównym naszym problemem. Trzeba, żeby człowiek odnalazł siebie i wytłumaczył sobie, że nic go nie uchroni od niego samego - nawet najpewniejszy dowód na istnienie Boga ${ }^{19}$.

Ludzkie czyny nie mogą być relatywne. Wybierając siebie, wybieramy za wszystkich ludzi. „W istocie każdy nasz czyn, poprzez który stwarzamy w sobie człowieka według własnej woli, pociąga jednocześnie za sobą stworzenie wzoru człowieka takiego, jaki według nas być powinien"20. Możemy uczynić cokolwiek, gdyż jesteśmy wolni. Będąc wolni, ustanawiamy jednak pewne możliwości, wzorce człowieczeństwa, które inni mogą naśladować. Stwarzając te wzorce, ponosimy odpowiedzial-

\footnotetext{
12 Ibidem, s. 105.

13 Ibidem, s. 402.

14 F. Nietzsche, Wiedza radosna, przeł. L. Staff, Warszawa 1911, s. 288.

15 Ibidem, s. 168.

16 Por. ibidem.

17 J.P. Sartre, Egzystencjalizm jest humanizmem, przeł. J. Krajewski, Warszawa 1998, s. 27.

18 Ibidem, s. 26-27.

19 Ibidem, s. 38.

20 Ibidem.
}

Miscellanea Posttotalitariana Wratislaviensia 8, 2020

(C) for this edition by CNS 
ność za wszystkich, którzy pójdą naszymi śladami. Brak Boga nie zdejmuje zatem z naszej wolności odpowiedzialności. Wręcz odwrotnie, tym bardziej nam ją uświadamia.

Żyjemy w czasach, w których dominują dwa niebezpieczeństwa: lęku przed wolnością i absolutyzacji wolności. Z jednej strony lękamy się wolności, gdyż wymaga ona odwagi, stanięcia w prawdzie, samodzielnego myślenia, twórczego wysiłku i odpowiedzialności. Z drugiej strony to absolutyzacja wolności. Wolność nie jest celem w sobie samym. Nie jest czymś absolutnym, wolnością czynienia czegokolwiek, zerwanych więzi, jak w demokracji opisywanej przez Platona. W państwie „demokratycznym po wszystkich kątach rozbrzmiewa hasło wolności. Ojciec boi się tu syna, a syn, chcąc być wolny, nie boi się rodziców. Nauczyciel boi się uczniów i im pochlebia, a młodzi ludzie upodabniając się do starszych nic sobie nie robią z nauczyciela”. I dodaje Platon, że na ulicy nawet zwierzęta go potrącają: „I w ogóle w ten sposób, gdzie się tylko ruszyć, wszędzie pełno wolności”21. Do wolności trzeba być dojrzałym. Demokracja w społeczeństwach bezmyślnych, bezkrytycznych, pozbawionych obywatelskich cnót, może odwrócić się we własne przeciwieństwo. Ważne jest to być wolnym. Nie mniej jednak ważne jest to, co jest treścią naszej wolności.

\section{Bibliografia}

Bergson, Henri. 1963. Oeuvres. Edition du centenaire. Red. André Robinet. Paris: Presses Universitaires de France.

Buber, Martin. 1968. „Wychowanie”, Znak 166: 449.

Gromczyński, Wiesław. 1969. Człowiek, świat rzeczy, Bóg w filozofii Sartre’a. Warszawa: PWN.

Hegel, Georg W.F. 1969. Zasady filozofii prawa. Przeł. Adam Landman. Warszawa: PWN.

Ingarden, Roman. 1989. Wykłady z etyki. Oprac. Adam Węgrzecki. Warszawa: PWN.

Mounier, Emmanuel. 1961-1962. Oeuvres Completes, t. 3. Paris: Éditions du Seuil.

Nietzsche, Friedrich. 1908. Tako rzecze Zaratustra. Ksiażka dla wszystkich i dla nikogo. Przeł. Wacław Berent, Warszawa: J. Mortkowicz.

Nietzsche, Friedrich. 1911. Wiedza radosna. Przeł. Leopold Staff. Warszawa: J. Mortkowicz.

Platon. 1990. Państwo. Przeł. Władysław Witwicki. Warszawa: Alfa-Wero.

Sartre, Jean-Paul. 1956. Dramaty. Muchy; Przy drzwiach zamkniętych; Ladacznica z zasadami; Niekrasow. Przeł. Jerzy Lisowski, Jan Kott, Warszawa: PWN.

Sartre, Jean-Paul. 1983. Cahiers pour une morale (1947-48), Paris: Gallimard.

Sartre, Jean-Paul. 1998. Egzystencjalizm jest humanizmem. Przeł. Janusz Krajewski, Warszawa: Muza.

Przyjęto do druku/Accepted for publication: 10.07.2020

21 Platon, Państwo, Warszawa 1990, s. 447.

Miscellanea Posttotalitariana Wratislaviensia 8, 2020

(C) for this edition by CNS 